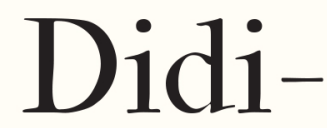

\title{
Huberman
}

\section{and the}

image Chari 


\section{Didi-Huberman and the image}

\section{MANCHESTER 1824}

Manchester University Press 
Chari Larsson - 9781526149275

Downloaded from manchesterhive.com at $04 / 26 / 2023$ 08:26:34AM 


\section{Didi-Huberman and the image}

Chari Larsson

Manchester University Press 
Copyright $\odot$ Chari Larsson 2020

The right of Chari Larsson to be identified as the author of this work has been asserted by her in accordance with the Copyright, Designs and Patents Act 1988.

Published by Manchester University Press

Altrincham Street, Manchester M1 7JA

www.manchesteruniversitypress.co.uk

British Library Cataloguing-in-Publication Data

A catalogue record for this book is available from the British Library

ISBN 9781526149268 hardback

First published 2020

The publisher has no responsibility for the persistence or accuracy of URLs for any external or third-party internet websites referred to in this book, and does not guarantee that any content on such websites is, or will remain, accurate or appropriate.

Cover design: Daniel Benneworth-Gray

Typeset by Newgen Publishing UK 